\title{
GEOSTRATEGIC CONTEXT OF NETWORKING OF NATIONAL MINORITY COMMUNITIES IN TERRITORIAL COOPERATION PROGRAMMES OF THE EU
}

\author{
Márton PÉTI ${ }^{\mathrm{a}}$, Csilla SZALÓKY-HOFFMANN ${ }^{\mathrm{b}}$ \\ ${ }^{a}$ Research Institute for National Strategy, Corvinus University of Budapest, Institute of Economic \\ Geography, Geoeconomy and Sustainable Development, Budapest, Hungary. E-mail: \\ marton.peti@nski.gov.hu \\ ${ }^{b}$ Research Institute for National Strategy, Budapest, Hungary. E-mail: csilla.hoffmann@nski.gov.hu \\ Cite this article: Péti, M., Szalóky-Hoffmann, Cs. (2016). Geostrategic Context of Networking of \\ National Minority Communities in Territorial Cooperation Programmes of the EU. Deturope, 8, 3: 156- \\ 169
}

\begin{abstract}
The participation of Hungary and Hungarian regions outside of Hungary in transnational and interregional programmes within the framework of the third objective (European Territorial Cooperation) of the European Union's Cohesion Policy 2007-2013 is an indicator suitable for analysing the international networking activity of Central European national minorities. These programme areas are very well in alignment with the settlement areas of Hungarians and thus it provides a great opportunity for cooperation in the field of regional developments. The study on the participation of Hungarian organizations in and outside of Hungary in the programming period of 2007-2013 shows; however, that Hungarian organizations outside of Hungary only partly utilize their networking potential and they worked with organisations of the mother country in only a few projects. Policies on cooperation may contribute to further utilize this networking potential.
\end{abstract}

Keywords: European Territorial Cooperation, minorities, international relationships, Central Europe, geopolitics, networking

\section{INTRODUCTION}

This study analyses the networking potential and performance of Central European national minority ${ }^{11}$ communities through their project activity in transnational and interregional territorial cooperation programmes of the $\mathrm{EU}^{12}$.

Central Europe has an especially colourful native population comparing to other macroregions of Europe. In the seven Central European countries east from Germany (Austria,

\footnotetext{
${ }^{11}$ Although the Central European minorities cannot be strictly divided into groups based on their history, territory, language or identity, national minorities are understood here as minority groups who have national collective consciousness and this is considered as crucial component of their community forming (Szarka, 1999).

${ }^{12}$ Territorial Cooperation Programmes of the EU Cohesion Policy 2007-2013:

- Hungary was involved in two transnational cooperation programmes: Central Europe Programme; South East Europe

- Interregional cooperation programmes (every EU Member States were involved): Interreg IVC, ESPON 2013 and URBACT Programmes
} 
Czech Republic, Poland, Slovakia, Hungary, Slovenia, Croatia) and in the three culturally, historically connected regions (Transcarpathia, the westernmost part of Ukraine; Transylvania, the western part of Romania; Vojvodina, the northern part of Serbia) there are 107 national, ethnic minority groups with more than a thousand people (Szarka, 1999). Typical of majority ethnic groups of certain countries that they appear in the macro-region's other countries as national minority groups. All these minority groups are native; they are not related to recent migration processes.

European integration has opened up a new and unique opportunity for the cooperation of the same ethnic groups living in different EU member states. As a result, it is worth examining what kinds of international relations are formed among the same ethnic groups in Central Europe where the national minorities are closely attached to their cultural identities.

The territorial cooperation programmes of the EU, inter alia, are those programmes that create opportunities for this kind of cooperation because the main objectives of territorial cooperation as defined by the EU are overcoming the negative effects of borders, maximising synergies and promoting joint solutions to common problems.

Spatial patterns of populous Hungarian minority communities in countries neighbouring Hungary are probably the most typical representation of this colourful Central European national mosaic. Therefore, the research outlined in this paper investigates the networking ability of Central European minority groups through the case of Hungarians.

\section{OBJECTIVES AND METHODS}

\section{Objectives of this study}

Analysing European policies and evaluations of territorial cooperation programmes, a high networking potential can be assumed in case of Central European national minority communities living in different countries. Some territory-related European policy intentions support their cooperation implicitly. Logics and experiences of existing European territorial cooperation mechanisms also imply their intensive networking possibilities.

This study aims to examine the potential and performance of territorial cooperation of national minorities living in different Central European countries. An intensive international cooperation potential can be hypothesized among minority communities sharing a common ethnic background but living in different countries. This networking potential shall be relatively higher than the one detected among different groups without an ethnic consciousness. 


\section{Methods of this study}

This research investigates the activity of Central European national minorities in the territorial cooperation programmes of the European Union.

A special understanding of 'Central Europe' and a narrow geographical scope of investigations had to be applied because of the objectives and methods of this research. In this paper the term of 'Central Europe' represent European Union member states joining EU between 2004 and 2013, and additionally Serbia and Ukraine. However, the investigations outlined in this paper are focused only on countries neighbouring Hungary. This territory is the Carpathian Basin, where the subjects of our study, the Hungarian minority communities are located.

In this paper networking ability of Central European national minorities were investigated through the case of the most populous Central European minority group, the Hungarians. These investigations on Hungarians can be considered as an introductory case study to get closer to general networking features of Central European minorities. This study maps the activities of and cooperation among Hungarian groups in the EU territorial cooperation programmes.

Several arguments can be set up why Hungarians represent suitable subject for this kind of investigations. Hungarians live in great numbers as minorities in countries out of Hungary. According to the latest census in 2011, 11.95 million Hungarians live in the Carpathian Basin. Notable size of Hungarian minorities live in Romania (Erdély/Transylvania) (6.5\% of the population of Romania in 2011), in Slovakia (Felvidék/Upper Hungary) $(8.5 \%$ of the population of Slovakia in 2011), in Serbia (Vajdaság/Vojvodina) (3.5\% of the population of Serbia in 2011) and in Ukraine (Kárpátalja/Transcarpathia) $(0.3 \%$ of the population of Ukraine in 2001). (There are Hungarian communities living in Austria, Croatia and Slovenia but in a much smaller number and proportion as compared to the previous countries.) It is estimated that about 2.4 million Hungarians live in the former four countries, about $50 \%$ of them in Romania (Kapitány, 2015).

In Slovakia and Ukraine most of the Hungarians live alongside the Hungarian border in a narrow range. In Romania and Serbia, the Hungarian minorities live in larger areas. Also unique in Europe is the settlement area of Székely/Szekler Hungarians living in an ethnic block. This relatively populous and large area with Hungarian majority is located several hundred kilometers far from Hungary in which the majority of population is Hungarians. Approximately $38 \%$ of the Hungarian minority in Romania lives there in Szeklerland (Kiss Barna, 2012). 
The populous and geographically broadly scattered Hungarian communities could establish institutional structures in many countries with a potential for taking part as partners in projects financed by the above mentioned European programmes.

The Hungarian language is fundamentally differs from other Central European languages, similarly to the Hungarian naming traditions. Therefore, project partners suspected to be related to Hungarian minority communities are effectively and confidently identifiable in project databases not requiring extended field studies.

The territorial cooperation programmes support three types of cooperation: cross-border, transnational and interregional projects. The transnational and interregional programmes provide a great opportunity for the Hungarian communities for strengthening the cooperation as the programme areas are very well in alignment with the settlement areas of Hungarians. They are fully or partly cover the eight countries and the potential beneficiaries include any public institutions representing the participating countries. It is of special importance that the main decision-making bodies of the programmes are Monitoring Committees consisting of delegates from every Member State which serves the objective character of decision-making.

In the absence of previous similar Hungarian or European studies this study developed its own data base and methodology. The data base developed by the study is based on the data of KEEP elaborated by the INTERACT programme of the EU (downloaded: April 2015). In the database involving two relating transnational programmes (Central Europe and South East Europe) where Hungary is involved and every relevant interregional programmes (ESPON, URBACT, INTERREG IVC) the following types of data have been available for each project: project's name, lead partner's and partners'name, their address and the project budget. Based on these data the main target group of the research can be confidently identified, i.e Hungarian project partner organisations of the neighbouring countries related to Hungarian ethnic communities. The analysis is also limited by these types of data of the European database (e.g. budget for each project partner is not available).

Data base of this study was analysed mostly through simple quantitative data comparison. In case of some projects with partners suspected to be related to Hungarian minority communities, qualitative information purchasing was applied as well to verify their relevance.

\section{European territorial policy context of development cooperation of national minorities}

However there is no European development policy message addressing explicitly native national minorities, there are some territorial policy logic that can effect on development cooperation of these minorities. 
The Territorial Agenda 2020 of the European Union (TA2020) identifies cultural heritage as part of territorial capital and identity as well as cultural assets as crucial factor for wellbeing and economic prospects which offer unique development opportunities. The policy document also emphasizes that improvement of regional and local identity by strengthening awareness and responsibility of local and regional communities towards their cultures and other unique values is of great importance. According to Territorial Agenda 2020, territorial cooperation can create a critical mass for development, decreasing economic, social and ecological fragmentation, increasing mutual trust and strengthening social capital. From this point of view, Central European minority ethnic groups possess great development potential because of their strong regional and local identities with a special spatial dimension of living in different countries.

Common cultural heritage crossing borders is also an important feature of Central European national minorities. TA2020 calls for local, regional and trans-regional management of cultural heritage of regions. Third objective of Cohesion Policy in 2007-2013 can also be considered as a tool for the management of cultural heritage on these scales, especially for the trans-regional scale. The transnational and interregional cooperation can provide new development perspectives by the utilization of cultural diversity and also the reunification of common cultural assets (Radvánszki-Sütő, 2011).

\section{Evaluating European territorial cooperation in relation to national minorities}

Most relevant literature on the performance of European development networks shall be found among evaluation studies of European territorial cooperation programmes. These programmes became widely accessible for Central European countries in the 2007-2013 programming period, after the EU enlargement. Obviously, overarching assessment including all the projects of 2007-2013 are expected after the closure of the programme period. Research related to the period 2000-2006 have been conducted can also be relevant for investigations outlined by this paper. Spatial pattern of native Central European national minority communities is not concentrated only on border zones where cross border cooperation is available. These communities frequently occur far away from state borders. However the most numerous minority group, the Hungarians, live historically close to the border of Hungary, even in this case of a significant proportion of Hungarian minority population is located far away from border zones. Therefore, evaluations of so called European interregional and transnational programmes with a programming area encompassing all territories of Eastern and Central European countries can provide this research with most 
relevant networking experiences. (There are some other reasons why these latter programmes can serve as suitable context for realising objective investigations on the performance of minority networking. These reasons are related first of all to the decision making mechanisms of these programmes.) It is not really favourable from the point of view of this research that considerably more articles deal with analysing cross-border cooperation of border zones than with transnational and interregional context (a reason for that can be the highest share of resources of Territorial Cooperation Objective allocated to cross-border cooperation).

The networking performance of territorial cooperation programmes were examined in the last ten years by several research projects but none of them indicated ethnic correlation (Jančič, 2005, Davoudi, 2005; Böhme, 2005; Zaucha - Szydarowski, 2005; BBR, 2009; Tatasciore, 2007; Kochanska, 2009; Mirwaldt-McMaster-Bachtler, 2009; Ploszaj, 2013). However, according to Böhme (2005), cooperation are characterised by interdisciplinary and transnational diversity which involves working within the constraints of one or more foreign languages and the cultural diversity of the team.

Networking of same national minorities living in different countries means networking without language barriers. This can result in a high networking potential of national minorities.

One of the most overarching assessments of territorial cooperation programmes of the period 2007-2013 conducted in the framework of one of the interregional programmes called ESPON 2013 can also be relevant in case of networking of national minority communities. The main objective of the ESPON TERCO project was to assess the relationship between territorial cooperation and the socio-economic development of EU and neighbouring regions (ESPON TERCO, 2012). It highlighted the possible links between territorial cooperation and territorial development, while showing that more research is needed to establish this link. ESPON TERCO report underlines the role of globalisation which has led to the weakened state control over national economies by ever increasing interconnections. Although this process of 'de-territorialisation' means national borders becoming more permeable, territory remains an important determinant factor of people's cultural identities, of economic development and living standards and of political decision-making. Reduced role of national scale results in a shift to other territorial scales such as supranational (e.g. the EU), subnational (regions or municipalities) and even transnational (crossing national borders).

Spatial patterns of Central European national minorities are represented typically on these latter scales having an emerging importance. 
ESPON TERCO report also describes bottom-up approach on cooperation between cities and regions of different countries. Contact and networking features of cooperation lead the scientists to the concept of 'paradiplomacy' which means the involvement of subnational governments in international politics (Keating and Hooghe, 1996). The study refers to an example of French and British towns as first forms of bottom-up territorial cooperation developed mainly as a result of municipal activism in the postwar period. They have been engaging in their own foreign diplomacy since the 1940s in the framework of town twinning. According to experts, European integration provides subnational actors with many opportunities to achieve their political or economic objectives independent of national channels. Assuming regional politicians are autonomous actors, territorial cooperation can be described as a bottom-up initiative where regional actors aim to cooperate because it serves their interests (ESPON TERCO, 2012).

Central European national minority communities provide excellent opportunities to realise such cooperation. Networking of groups sharing common ethnic background in different countries can stimulate other actors of these countries to get into contact each other. This latter process can also be supported by multiple national identities occurring frequently among Central European national minority communities (Szarka, 1999).

\section{RESULTS}

\section{General networking performance of Hungarian minority communities}

Exploring the overall programme activity of the countries hosting the Hungarian minority groups helps to evaluate further the performance of Hungarian minority communities. Concerning the activity of the neighbouring countries the performance of Slovakia measured by number of partners per population is above the average, that value of Romania is around the average. The value of relative participation in transnational programmes is higher than that in the interregional progammes for the three countries examined (Fig. 1). 
Figure 1 Number of partners per population in those transnational and interregional territorial cooperation programmes where Hungary is involved (per 10 million inhabitants) (2007-2013) Romania, Slovakia and Hungary

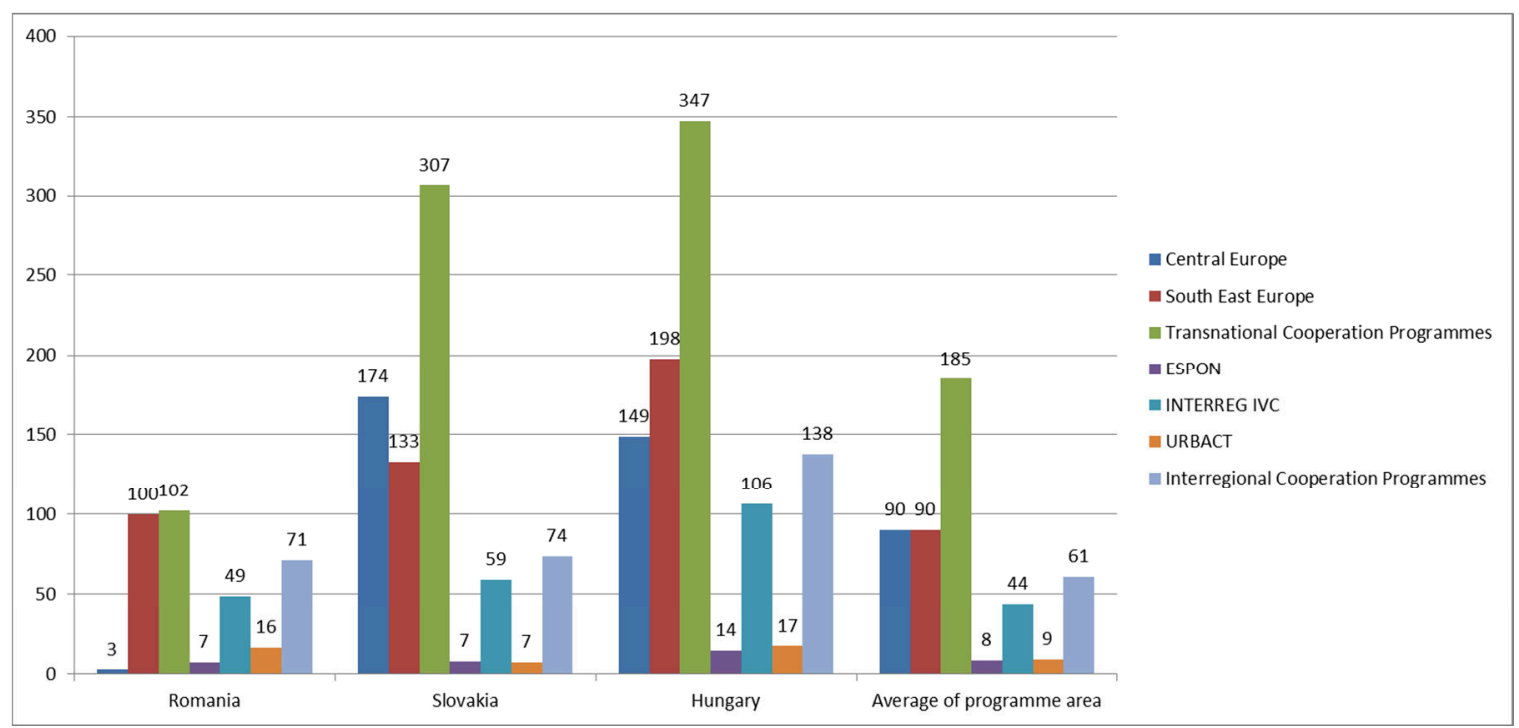

Source: by Péti - Hoffmann, 2016 (source of data: www.keep.eu)

The proportion of Hungarian participants remained below the proportion of the Hungarian minority in the given neighbouring country in case of every examined country (Tab. 1). While the participation rates of organisations of the neighbouring countries related to Hungarian ethnic communities in Romania were $4 \%$ and in Serbia $1.5 \%$, those in Slovakia was quite low and there was no Hungarian participation in Ukraine.

Table 1 The proportion of Hungarian population and participation of organisations of the neighbouring countries related to Hungarian ethnic communities in those transnational and interregional territorial cooperation programmes where Hungary is involved (2007-2013)

\begin{tabular}{|l|c|c|c|c|}
\hline & Romania & Serbia & Slovakia & Ukraine \\
\hline $\begin{array}{l}\text { Proportion of Hungarian } \\
\text { minority population in } \\
\text { the given country (\%) }\end{array}$ & 6.5 & 3.5 & 8.5 & 0.3 \\
\hline $\begin{array}{l}\text { Number of project } \\
\text { participation of } \\
\text { organisations of the } \\
\text { neighbouring countries } \\
\text { related to Hungarian } \\
\text { ethnic communities in the } \\
\text { total participation of the } \\
\text { given country }\end{array}$ & $14(4 \%)$ & $2(1.5 \%)$ & $1(0.5 \%)$ & 0 \\
\hline
\end{tabular}


This low-intensity Hungarian participation was highly concentrated. There were some experienced partners participated in more projects in this type of projects for example the Council of Harghita County. There were 17 projects which involved Hungarian partners from the neighbouring countries and that was implemented by only 11 partners. None of the Hungarian partners from outside of Hungary (not even the experienced ones) were lead partners in the projects.

\section{Networking of Hungarian communities in the framework of territorial cooperation programmes}

Number of projects involving Hungarian partners from both Hungary and outside of Hungary represents an extremely low proportion of all the projects involving Hungary (Tab. 2), however the programme areas, especially the South East European, fully cover the areas of the Carpathian Basin where Hungarians live. In this sense these programmes could be suitable for Hungarian-Hungarian cooperation especially because they are not limited geographically like the cross-border cooperation.

Table 2 Projects with the participation of Hungarian partners from Hungary and organisations of the neighbouring countries related to Hungarian ethnic communities by programmes

\begin{tabular}{|c|c|c|c|}
\hline $\begin{array}{c}\text { Programmes with } \\
\text { Hungarian-Hungarian } \\
\text { cooperation }\end{array}$ & $\begin{array}{c}\text { Number of projects } \\
\text { with Hungarian- } \\
\text { Hungarian cooperation }\end{array}$ & $\begin{array}{c}\text { Propotion of } \\
\text { projects with } \\
\text { Hungarian- } \\
\text { Hungarian } \\
\text { cooperation } \\
(\%)\end{array}$ & $\begin{array}{c}\text { Total number of } \\
\text { projects with } \\
\text { participation from } \\
\text { Hungary (=100\%) }\end{array}$ \\
\hline South East Europe & 11 & 5.5 & 196 \\
\hline Interreg IVC & 2 & 2 & 105 \\
\hline URBACT & 1 & 5.9 & 17 \\
\hline
\end{tabular}

Source: by Péti - Hoffmann, 2016 (source of data: www.keep.eu)

Hungarian-Hungarian cooperation ${ }^{13}$ projects only occurred in the South-East European programme area, but even there only $5 \%$ of the projects could be considered that type. It is only one project (SEEMIG) implemented in the South East European programme which involved Hungarian partners from more than two countries: Hungary, Serbia and Romania. Otherwise only bilateral Hungarian connections were observed in projects, and Hungary (partners from Hungary) represented always one of the countries in these bilateral contexts.

\footnotetext{
${ }^{13}$ Hungarian-Hungarian cooperation can be desribed as cooperation between a Hungarian partner from Hungary and a partner from the certain neighbouring country who is related to its Hungarian national minority
} 
Still, surprisingly, partners from Hungary have worked together more frequently with nonHungarian partners coming from the neighbouring countries than with Hungarians (Tab. 3.).

Table 3 Participations with the cooperation of Hungarian partners from Hungary and organisations of the neighbouring countries related to Hungarian ethnic communities (\%)

\begin{tabular}{|l|c|c|c|}
\hline & Romania & Serbia & Slovakia \\
\hline $\begin{array}{l}\text { Number of participations } \\
\text { interpreted as Hungarian- } \\
\text { Hungarian cooperation }\end{array}$ & 12 & 2 & 1 \\
\hline $\begin{array}{l}\text { Proportion of participations } \\
\text { interpreted as Hungarian- } \\
\text { Hungarian cooperation (\%) }\end{array}$ & 8.5 & 2.9 & 0.9 \\
\hline $\begin{array}{l}\text { Total number of participations } \\
\text { with the partnership of } \\
\text { Hungary and the given } \\
\text { country (=100\%) }\end{array}$ & 141 & 69 & 109 \\
\hline $\begin{array}{l}\text { Proportion of Hungarian } \\
\text { population in the given } \\
\text { country }(\%) \text {. } \%\end{array}$ & 6.5 & 3.5 & 8.5 \\
\hline
\end{tabular}

Source: by Péti - Hoffmann, 2016 (source of data: www.keep.eu)

Only $4.7 \%$ of the projects had Hungarian-Hungarian cooperation which means the cooperation of a Hungarian partner from Hungary and a partner from a given neighbouring country related to its Hungarian national minority. In case of some countries that percentage reaches the proportion of the Hungarian population, but never significantly exceeds that as would otherwise be expected. The Hungarian-Romanian cooperation projects produced the best results in that regard: $8.5 \%$ of all the projects had Hungarian-Hungarian cooperation, but even that is just two percentage points higher than the proportion of the Hungarian population (this is caused mainly by the active participation of Council of Harghita County). The Hungarian-Hungarian cooperation was present in just $0.9 \%$ of all the Hungarian-Slovak cooperation projects, which is far lower than the Hungarian population ratio in Slovakia. The Hungarian-Hungarian cooperation was present in $2.9 \%$ of the total Serbian-Hungarian projects which is also lower than the Hungarian population ratio of $3.6 \%$. No such projects could be identified in Ukraine.

In Hungary there were no institutions specialized in Hungarian-Hungarian cooperation. This is confirmed by the fact that the 36 project participation involved nearly the same number of partners from Hungary (which means that one partner participated in only one 
project). As opposed to Hungary there were institutions specialized in Hungarian-Hungarian cooperation in the neighbouring countries, illustrated by fact that the 16 project participations were carried out by just 10 Hungarian partners (e.g Council of Harghita County).

Nearly half of the projects with Hungarian-Hungarian cooperation were led by an institute from Hungary (7 lead partnership roles). In these cases networking among institutes using the same working language (Hungarian) could contribute to creating project proposals. However this could not be a guiding principle of generating these projects, as the vast majority of their partners were not from Hungary and had no Hungarian minority background.

The participation of Hungarian national minority communities was probably entirely initiated by other project partners from Hungary. Partner organisations of the neighbouring countries related to Hungarian ethnic communities only participated in projects having also partners from Hungary (with only one exception).

\section{DISCUSSION}

In order to understand the results better it is worth taking a closer look at policy context of these programmes in Hungary. Although the participation of partners from Hungary in the analysed programmes is outstanding in European comparison, the participation rate of ministries and central institutions - also by European comparison - low (rate of central institutions among partners from Hungary: 4.1\%; the same in case of Austria: 7.4\%; Romania: 8.3\%; Slovakia: 6.7\%). Among the projects having Hungarian-Hungarian dimension there were projects both with and without the participation of central administrative partners. In the examined programming period no significant policy on stimulating Hungarian-Hungarian partnerships in these programmes can be identified. In this manner results above reflect an objective overview on the organic participation and networking abilities of minorities. As a consequence, the Hungarian-Hungarian cooperation analysed can be definitely interpreted as bottom-up initiatives and thus they are a more "paradiplomacy" type of collaboration.

According to the results, communities in countries of national majority (in our case Hungary) are the ultimate drivers of organising the cooperation among the same national communities of different countries. Hungarian minority communities were only able to take part in projects with a partner from Hungary, from a country where Hungarian consist majority.

Networking among communities with a same national background living in different countries is not really an important driver of project planning in the examined programmes. 
At least it was the case at the populous Hungarian communities and in Hungary: choosing a Hungarian partner was not as frequent as to choose a partner with other national and language background from the same country. There was no partner in Hungary specialized in involving partners from Hungarian minorities. Even out of Hungary only one experienced partner institute could be identified with a kind of specialization in taking part projects possessing also a Hungarian-Hungarian dimension.

Summarising results, the detected networking activity of Hungarian communities in the examined programmes can be considered lower from certain aspects than it could have been expected according to great cooperation potentials of this population. This is even more surprising by taking into account the significantly high activity of partners from Hungary.

The sociogeographical context of the Hungarian minorities can be an explanation for these figures. A really significant, even dominant proportion of the Hungarian minorities live in rural communities (Péti - Szabó, 2015). International networking ability of rural community’s institutions are obviously lower than the average. This is especially the case of Hungarians living in Slovakia, where the relatively lowest programme activity was identified.

Reasons behind the detected performance shall obviously be very various requiring further investigations, first of all in fields of institutional and financial ability, national identity attitudes in Hungary and outside, decision making procedures of programmes and the timeline of the networking activities. The performance of other Central European national minorities would be worth investigating as well.

In spite of the needs for further investigations, the current results can unambiguously verify the importance of building policies and development actions more intensively and strategically on the existing networks of national minorities. The possibility of cooperation among national minority groups should be utilized in these programmes which could be supported by direct national and European policy as well.

\section{CONCLUSION}

In Central Europe many native communities share the same national and language background and live in different countries. These Central European national minorities can have a high potential in building development networks among countries, possibly higher than communities without this special feature. According to the research of this study, networking of Hungarian communities of different countries in projects financed by territorial cooperation programmes of the EU is not significantly high, it can also be considered relatively low from 
some aspects. Policies and development actions shall more intensively and strategically be built on the existing networks of Central European national minorities.

\section{REFERENCES}

Böhme, K. (2005). The ability to learn in transnational projects. Informationen zur Raumentwicklung 11/12.2005, 691-700.

Celińska-Janowicz, D., Zawalińska, K. \& Widła-Domaradzki, L. (2013). Structural Equation Model of Successful Territorial Cooperation In: Gorzelak, G. - Zawalińska, K. (eds.): European Territories: From Cooperation to Integration? Warszawa: Wydawnictwo Naukowe Scholar (pp. 134-154.)

Davoudi, S. (2005). Transnational co-operation and its contribution to territorial cohesion. Informationen zur Raumentwicklung 11/12.2005, 683-689.

ESPON TERCO European Territorial Cooperation as a Factor of Growth, Jobs and Quality of Life (2012) Scientfic Report. ESPON \& EUROREG - Centre for European Regional and Local Studies, University of Warsaw

Jančič, M. (2005). INTERREG IIIB in Slovenia. Informationen zur Raumentwicklung 11/12.2005, 741-748.

Kapitány, B. (2015). Külhoni magyar közösségek. in: Spéder, Zs. (ed.): Demográfiai Portré 2015, KSH Népességtudományi Kutatóintézet

Keating, M., \& Hooghe, L. (1996). By-Passing the Nation-State? Regions and the EU Policy Process. In: RICHARDSON, J. J. (ed.) European Union: Power and Policy Making. London: Routledge

Kiss, T., \& Barna, G. (2012). Népszámlálás 2011.Erdélyi magyar népesedés a XXI. század első évtizedében. Demográfiai és statisztikai elemzés. Nemzeti Kisebbségkutató Intézet, Kolozsvár.

Kochańska, E. (coordinator) (2009). Added value of European Territorial Cooperation for regional development of Poland in the context of cohesion policy after 2013. Association of Economic Consultants Pro-Akademia. Lódź

Mirwaldt, K., McMaster, I., \& Bachtler, J. (2009). Reconsidering Cohesion Policy: The Contested Debate on Territorial Cohesion. European Policy Research Paper, 66, European Policies Research Centre, University of Strathclyde

Péti, M., \& Szabó, B. (eds.) (2015). A Kárpát-medencei külhoni Magyarság társadalmigazdasági helyzete és lehetséges fejlesztési irányai. Nemzetstratégiai Kutatóintézet

Płoszaj, A. (2013). Two Faces of Territorial Cooperation in Europe: Twinning Cities and European Territorial Cooperation Programmes In: Gorzelak, G., \& Zawalińska, K. (eds.): European Territories: From Cooperation to Integration? Warszawa: Wydawnictwo Naukowe Scholar (pp. 69-96.)

Radvánszki, Á., \& Sütő, A. (2011). A Területi Agenda felülvizsgálatának megalapozása: az Európai Unió területi helyzetének és kilátásainak újragondolása. Falu Város Régió 2011/1.

Szarka, L. (1999). A közép-európai kisebbségek tipológiai besorolhatósága. Kisebbségkutatás 1999.2. szám

Tatasciore, R. (team leader) (2007). Effectiveness and Impact Assessment of INTERREG IIIC Operations on Regions located in the INTERREG III C East Zone Final Report Phase B. Vienna

Territorial Agenda of the European Union 2020 (2011).

Wilke, N. (ed.) (2009). Impacts and Benefits of Transnational Projects (INTERREG III B). Federal Office for Building and Regional Planning, Bonn. 
Péti, M., Szalóky-Hoffmann, Cs.

Zaucha, J., \& Szydarowski, W. (2005). Transnational co-operation and its contribution to spatial development and EU enlargement. The case of INTERREG IIIB in Northern Poland. Informationen zur Raumentwicklung 11/12.2005, 731-740. 